УДК

\title{
EVALUATION OF MOTOR TRANSPORT ENTERPRISE INVESTMENT POTENTIAL
}

\section{O. M. Zagurskiy}

National University of Life and Environmental Sciences of Ukraine, Ukraine.

Speciality of article: 275 - transport technologies (by road).

Corresponding author: zagurskiy_oleg@ukr.net.

Article history: Received-April 2020, Accepted-August 2020.

Bibl. 10, fig. 0, tabl. 5 .

Abstract. In the present circumstances, increasing of the motor transport enterprises efficiency contributes to the growth of its own competitiveness, has a significant influence on the competitiveness of their counterparties and the general level of competitiveness of the country's economy too. Therefore, the issue of improving the methods of evaluation of motor transport enterprises efficiency and search for new approaches of measuring of their investment potential is relevant.

The purpose of the article is to develop economic and mathematical methods for evaluation of motor transport enterprise investment potential

The approach to generalizing the system of indicators for evaluation of motor transport enterprise investment potential was developed in the article. Procedure for conducting an investment potential analysis is based on the calculation of qualitative and quantitative indicators of the efficiency of motor transport enterprises activity. Function of desirable is the main tool of this methodological approach, that is complemented by the integrated coefficient calculation and using an objective-structural approach to reduce the subjectivity of non-formalized indicators.

The proposed integrated indicator of the motor transport enterprise investment potential level gives an opportunity to comprehensively approach to an activity efficiency and enterprise management evaluation and identify the individual processes that need to be improved. Realization of the developed measures gives an opportunity to increase the overall efficiency of a motor transport enterprise management and increase its investment attractiveness for potential investors.

Key words: motor transport enterprise, efficiency, investment potential, integrated indicator, complex analysis.

\section{Introduction}

Under modern economic conditions and globalization processes, the enterprise has been increasingly becoming a complex, dynamic system which is able to improve and self-organize on account of increasing the efficiency of production processes. The importance of efficiency in production, investment and financial activities, the equilibrium and flexibility of strategic and tactical management decisions of business entities have been objectively increasing.

\section{Formulation of problem}

For the enterprises in the motor transport sector, as participants in the production processes for the movement of various cargoes in space and time, the responsibility for management decisions taken and the consequences of their economic activity has a special meaning. Since, their effectiveness contributes not only to the growth of their own competitiveness, but also significantly affects the competitiveness of customer enterprises and the overall level of the country's economy competitiveness. Thereby the role of operational analysis of the activity of the motor transport enterprise which should occupy a central place in the enterprise management system in general.

\section{Analysis of recent research results}

Features of performance evaluation and realization of investment potential of motor transport enterprises have been highlighted in the writings of AV Bazylyuk [1], VP Gudkova [2], O.D. Shcherban [3]. Modern approaches to assessing the logistic activity of enterprises are devoted to the attention in the works of T. Wang [4], J. Koyla [5], R. Larina [6] and others [710]. But these directions of analysis can provide only internal decision making on the effective the enterprise potential usage, the need for innovation, and respectively investment needs (real or financial). For potential investors, these data are not enough or in reverse their versatility and diversity do not make it clear if the company is attractive for investment and if so, to what extent is it. That is an investor faces uncertainty while making a decision which can lead to worse consequences than a false decision. Therefore, there is a need for 
continuous improvement of evaluation methods and analysis of new approaches regarding measuring the investment potential of motor transport enterprises.

\section{Purpose of research}

The purpose of research is economic-mathematical methods development for assessing of a motor transport enterprise investment potential, searching for a new tools for determining its level.

\section{Research results}

Increasing the efficiency of motor transport enterprises, the ability to adapt to modern requirements, and respectively the ability to keep up a high level of development in the long run are the main criterion for ensuring the formation of prerequisites for the progressive and sustainable development of both the transport industry and the Ukrainian economy. The transformation of social relations and the formation of the knowledge economy are especially actualizing the question of assessing the level of efficiency of motor transport enterprises as they have a specific two-way role in economic processes. On the one hand they are the service industry which is providing transport services to organizations and population. On the other hand, carrying out transit it is a branch of material production, since they continue the production process and recently they are increasingly taking on non-transport functions, freeing consumers from sales and distribution operations. So shipping ceases to be a separate sector of the economy. Given this the level of performance of the functions of the motor transport enterprise significantly depends on the availability of certain knowledge and the ability to use them as innovative products and technologies. Combination of transport services and logistics services is one of these modern technologies, that is the creation of enterprises capable of of giving integrated transport and logistics services, since "increasing the efficiency of transport can change the overall efficiency of the logistics system" [7, p. 1671]. Under such conditions the content of the activity of transport enterprises changes itself which is now determined not so much by the technical and commercial exploitation of vehicles, how the ability to effectively manage product and information flows whose quality are extend depended on the qualifications and skill of the staff. The estimation of investment potential level of such enterprise should accordingly take into account not only economic and technical indicators, because they do not take into account many important intangible benefits and substantial intangible costs which accompany transport activities. Beside that it is important to integrate into the system and indicators of the implementation of specific logistic actions and indicators of the professional characteristics of employees. So the general system of criteria for investment potential of motor transport enterprises should take into account the indicators of both internal and external influences, and therefore it should be more complex and balanced.

Complexity in this section suggests a comprehensive assessment of the enterprise economic potential, or, in other words, it allows to provide identification of its place in the economic environment of the industry, region, etc. For the complex analysis of the enterprise it is typical estimation of trends of the most common indicators, which characterize its condition from different directions. In return, "the balance determines the company's ability to achieve the purpose of the activity, since the different levels of individual components development of potential opportunities complicates, or even makes it impossible the process of effective operation of the enterprise " [8, p. 72]. And in aggregate the usege of both criteria makes it possible to build a holistic system for estimation of enterprise activity efficiency which most accurately reflects its investment potential.

An approach that most closely meets these requirements when making managerial decisions under uncertainty is a cognitive approach which aimed at identifying dependencies and patterns of potential and behavior of the business entity. It essentially relies on both the management system and the human consciousness and takes into account both internal and external factors that have an impact on the enterprise. That is, it simultaneously uses both SWOT-analysis to identify the strengths and weaknesses of the enterprise and PEST-analysis to assess the external economic situation.

However, the effectiveness of such analysis depends on the possibility of constructing an adequate system of unambiguity of the mathematical processing interpretation results of a defined group of target indicators in order to prevent and avoid the doublemeaning of the conclusions, contradictions in the views of individual experts regarding the object state identification of research. In order to ensure an adequate transfer of the quantitative value of the generalizing indicator of the motor transport enterprise efficiency we used the so-called desirable function (Harrington scale) in our qualitative assessment [9].

Table 1. Characteristics of investment potential.

\begin{tabular}{|c|c|}
\hline Performance level values & Characteristics of investment potential levels \\
\hline $1.00-0.80$ & High level of investment potential \\
\hline $0.80-0.63$ & Average level of investment potential \\
\hline $0.63-0.37$ & The level of investment potential below average \\
\hline $0.37-0.20$ & Low level of investment potential \\
\hline $0.20-0.00$ & Unacceptable level of investment potential \\
\hline
\end{tabular}

Source: Harrington E.C.Jr. The desirability Function / E.C.Jr. Harrington // Industrial Quality Control, 1965.

April. V. 21. № 10. pp. 494-498 
Analysis procedure by using the desirability consists of three stages:

1. Analysis options selection;

2. Parameter values obtaining;

3. Merging of the obtained values into the generalized indicator, which characterizes the current level of investment potential in general.

The choice of specific methods and criteria for assessing the economic efficiency of vehicles companies first of all depends on the specifics of the situation and customer needs analysis. We proposed to use five groups of indicators as the general criteria of the integrated performance appraisal of vehicles enterprises.

1) economic potential of the Company (e);

2) technical potential of the Company (T);

3) organizational and intellectual potential of the Company $(\mathrm{O})$;

4) Information potential of the Company (i) (Z).

5) External operating conditions of the Company

According to the absolute value of the fading integrated indicator is calculated by:

$$
\begin{gathered}
Z=\alpha_{E} \times \sum_{i=1}^{n} \beta_{i}^{E} \times E_{i}+\alpha_{T} \times \sum_{i=1}^{n} \beta_{i}^{T} \times T_{i}+\alpha_{I} \times \sum_{i=1}^{n} \beta_{i}^{I} \times I_{i} \\
+\alpha_{O} \times \sum_{i=1}^{n} \beta_{i}^{O} \times O_{i}+\alpha_{Z} \times \sum_{i=1}^{n} \beta_{i}^{Z} \times Z_{i}
\end{gathered}
$$

where $-\alpha_{i}-$ the coefficients of the research directions;

$\beta_{i}-$ The coefficients of weight targets in separate directions.

Each group, in its turn, is formed from the parameters of the group, which together meet the requirements of the complex characteristics of the company current state and the prospects for its development in terms of development goals balance. In this case usage of a large number of indicators on the one hand can cause loss of time for mathematical and analytical maintenance of the investigations of functionally interdependent indicators, and on the second hand in the case of lack of interdependence between them lead to a large error in calculations. Therefore, it is offered reasonable usage (sufficient) of quantity (3), (4) indicators that are closely correlated with each other. The formula of the company's capacity to achieve a defined potential in groups is:

$$
K_{\mu}^{i}=\frac{\sum_{1}^{n} X_{i} \times \alpha_{i}}{n}
$$

where $R_{i}-$ is the level of the indicator; $\alpha_{i}-$ the significance of the indicator;

$\mathrm{n}$-is the number of indicators within the corresponding component of potential opportunities of the company.

Moreover, by the condition we assume: increasing of a separate indicator $\mathrm{X}_{\mathrm{i}}$ is connected with the efficiency increasing of considered motor transport company activity. If there is an opposite tendency for this metric, then in the analysis it should be replaced with the associated opposite value.

Each indicator $X_{i}$ compares the level of its significance for analysis $r_{i}$. To estimate this level, you need to arrange all the indicators in descending order of significance so that rule out

$$
r_{1} \geq r_{2} \geq \ldots r_{N}
$$

Ranking occurs using the Fishburne's rule [10]:

$$
\mathrm{r}_{\mathrm{i}}=\frac{2(\mathrm{~N}-\mathrm{i}+1)}{(\mathrm{N}-1) \mathrm{N}}
$$

To assess the effectiveness and level of investment

\begin{tabular}{|c|c|c|c|c|}
\hline № & Indicator & Capacity Group & $\begin{array}{c}\text { Weight of the } \\
\text { group }\end{array}$ & $\begin{array}{l}\text { Calculation } \\
\text { method }\end{array}$ \\
\hline $\mathrm{X} 1$ & Coverage coefficient & \multirow{3}{*}{ Financial } & \multirow{3}{*}{4} & \multirow{9}{*}{ 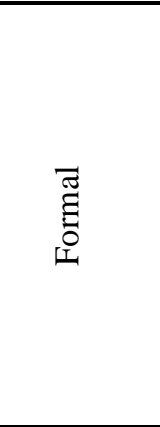 } \\
\hline $\mathrm{X} 2$ & Profitability Rate & & & \\
\hline $\mathrm{X} 3$ & Its provision coefficient & & & \\
\hline $\mathrm{X} 4$ & Wear coefficient of production facilities & \multirow{3}{*}{ Technical } & \multirow{3}{*}{4} & \\
\hline $\mathrm{X5}$ & The coefficient of transport performance & & & \\
\hline X6 & The coefficient of transport costs & & & \\
\hline $\mathrm{X} 7$ & Level of information support & \multirow{3}{*}{ Information } & \multirow{3}{*}{3} & \\
\hline $\mathrm{X} 8$ & Number of sources of information & & & \\
\hline X9 & Number of users information & & & \\
\hline $\mathrm{X} 10$ & Business reputation of the enterprise & \multirow{3}{*}{$\begin{array}{l}\text { Organizational- } \\
\text { intellectual }\end{array}$} & \multirow[b]{3}{*}{3} & \multirow{5}{*}{ 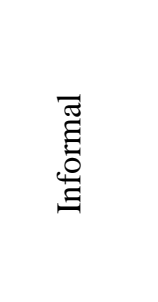 } \\
\hline $\mathrm{X} 11$ & Management level of the enterprise & & & \\
\hline $\mathrm{X} 12$ & Qualification level of company employees & & & \\
\hline $\mathrm{X} 13$ & $\begin{array}{l}\text { The level of investment attractiveness of the } \\
\text { region in which the company operates }\end{array}$ & \multirow{2}{*}{$\begin{array}{c}\text { External } \\
\text { conditions of } \\
\text { operation of the }\end{array}$} & \multirow[b]{2}{*}{2} & \\
\hline $\mathrm{X} 14$ & $\begin{array}{l}\text { Development of market institutions in the country where } \\
\text { the company operates }\end{array}$ & & & \\
\hline
\end{tabular}
potential of vehicles enterprises we build a system of 15 most important, in our opinion, for the automotive transport industry indicators.

Table 2. Performance indicators and level of investment potential of vehicles enterprises. 


\section{\begin{tabular}{|c|c|}
\hline X15 & Conditions of operation of transport for the
\end{tabular} natural-ecological state of the region}

Source: Compiled by author

And if the indicators of the first three groups are calculated by the formalized methods of describing analytical procedures on the basis of clear dependencies on the use of the mathematical apparatus of economic and financial analysis, the last two figures take into account the subjectivity mal constructed depending on the logical level of the use of expert opinions and assessments, and therefore can be subjective.

To reduce the subjectivity of indicators of the last two groups is possible by means of objectivelystructural approaches. In particular, those based on the rules of Fuzzy logic. Fuzzy-multiple method uses linguistic quantities and expressions to describe a defined potential of the company and it is ideally suited for planning factors in time, when their future assessment is blurred and has insufficient grounds for reliability. The task of deviations in the factors causes or enterprise consequences in the form of fuzzy sets is used in cases where an expert cannot accurately determine the deviation of the factor-consequences caused by a deviation of a factor. The function of affiliation of the value of the deviation of the factor-effect is given by a fuzzy set:

$$
\mu_{[0 ; 1]}\left(X_{s}^{r}\right)=\left\{X_{s_{1}}^{r} / V_{1}, X_{s_{2}}^{r} / V_{2}, \ldots ., X_{s_{n}}^{r} / V_{n}\right\}
$$

where, $\cdot X_{s_{1}}^{r}, \ldots, X_{s_{n}}^{r}$ - value factor after increasing,

$V_{l}, \ldots, V_{n}$ - subjective estimates of possibility of corresponding increments of factor at a given increment of factor-cause.

According to the unclear of plural approach, the classification of the current values of $\mathrm{X}$ indices as criteria for splitting the full set of its values into a subset of $\mathrm{V}$ are constructed.

Table 3. Taxonomy of current $x$ values.

\begin{tabular}{|c|c|c|c|c|c|}
\hline \multirow{2}{*}{$\begin{array}{c}\text { Name of } \\
\text { indicator }\end{array}$} & \multicolumn{5}{|c|}{ Subset criterion } \\
\cline { 2 - 6 } & $\mathrm{B}_{\mathrm{i} 1}$ & $\mathrm{~B}_{\mathrm{i} 2}$ & $\mathrm{~B}_{\mathrm{i} 3}$ & $\mathrm{~B}_{\mathrm{i} 4}$ & $\mathrm{~B}_{\mathrm{i} 5}$ \\
\hline $\mathrm{X}_{1}$ & $\mathrm{x}_{1}<\mathrm{b}_{11}$ & $\mathrm{~b}_{11}<\mathrm{x}_{1}<\mathrm{b}_{12}$ & $\mathrm{~b}_{12}<\mathrm{x}_{1}<\mathrm{b}_{13}$ & $\mathrm{~b}_{13}<\mathrm{x}_{1}<\mathrm{b}_{14}$ & $\mathrm{~b}_{14}<\mathrm{x}_{1}$ \\
\hline$\cdots$ & $\cdots$ & $\cdots$ & $\cdots$ & $\cdots$ & $\cdots$ \\
\hline $\mathrm{X}_{\mathrm{N}}$ & $\mathrm{x}_{\mathrm{N}}<\mathrm{b}_{\mathrm{N} 1}$ & $\mathrm{~b}_{\mathrm{N} 1}<\mathrm{x}_{\mathrm{N}}<\mathrm{b}_{\mathrm{N} 2}$ & $\mathrm{~b}_{\mathrm{N} 2}<\mathrm{x}_{\mathrm{N}}<\mathrm{b}_{\mathrm{N} 3}$ & $\mathrm{~b}_{\mathrm{N} 3}<\mathrm{x}_{\mathrm{N}}<\mathrm{b}_{\mathrm{N} 4}$ & $\mathrm{~b}_{\mathrm{N} 4}<\mathrm{x}_{\mathrm{N}}$ \\
\hline
\end{tabular}

Source: Compiled by the author on the basis of vague-of plural approach.

Further, the assessment of the current level of indicators is conducted and the classification of their values, where $\lambda_{\mathrm{ij}}=1$, if $\mathrm{b}_{\mathrm{i}(\mathrm{j}-1)}<\mathrm{x}_{\mathrm{i}}<\mathrm{b}_{\mathrm{ij}}, \mathrm{i} \lambda_{\mathrm{ij}}=0$, and $\lambda_{\mathrm{ij}}=0$ otherwise (when the value does not fall into the selected classification range), and the obtained results are reduced in the table.

Table 4. Classification of the level of indicators.

\begin{tabular}{|c|c|c|c|c|c|}
\hline \multirow{2}{*}{ Name of indicator } & \multicolumn{5}{|c|}{ Classification result for subsets } \\
\cline { 2 - 6 } & $\mathrm{B}_{\mathrm{i} 1}$ & $\mathrm{~B}_{\mathrm{i} 2}$ & $\mathrm{~B}_{\mathrm{i} 3}$ & $\mathrm{~B}_{\mathrm{i} 4}$ & $\mathrm{~B}_{\mathrm{i} 5}$ \\
\hline $\mathrm{X}_{1}$ & $\lambda_{11}$ & $\lambda_{12}$ & $\lambda_{13}$ & $\lambda_{14}$ & $\ldots$ \\
\hline$\ldots$ & $\ldots$ & $\ldots$ & $\ldots$ & $\lambda_{\mathrm{N} 4}$ & $\lambda_{\mathrm{N} 5}$ \\
\hline $\mathrm{X}_{\mathrm{N}}$ & $\lambda_{\mathrm{N} 1}$ & $\lambda_{\mathrm{N} 2}$ & $\lambda_{\mathrm{N} 3}$ & 0,7 & 0,9 \\
\hline weight $(\mathrm{g})$ & 0,1 & 0,3 & 0,5 & $\ldots$ & $\ldots$ \\
\hline
\end{tabular}

Source: Compiled by the author on the basis of vague-of plural approach.

Completing formal arithmetic actions to assess the level of potential $\mathrm{g}$ :

$$
g=\sum_{j=1}^{5} g_{j} \sum_{i=1}^{N} r_{i} \lambda_{i j}
$$

Table 5. Classification of current value of $\mathrm{G}$ indicator.

\begin{tabular}{|c|c|}
\hline G-Value Interval & Subset \\
\hline $0.8<\mathrm{g}<1$ & G5-Extremely high level \\
\hline $0.6<\mathrm{g}<0.8$ & G4-High Level \\
\hline $0.4<\mathrm{g}<0.6$ & G3-Medium level \\
\hline $0.2<\mathrm{g}<0.4$ & G2-Minor level \\
\hline $0-0.2$ & G1-Extremely low level \\
\hline
\end{tabular}

Source: Compiled by the author on the basis of vague-of plural approach.

We classify the obtained values of the degree of their level on the database table. 
Thus, our conclusion about the level of potentials of the motor transport enterprise of the third and fourth groups acquires a linguistic form. So, as a result of the above procedures it is possible to become an attempt to combine and formalized methods of analyzing the potential of the motor transport company to the effective activities.

\section{Conclusions}

1. The developed approach generalizes a system of indicators of evaluation of investment potential of a motor transport enterprise and serves as a tool for determining its level. The procedure for carrying out an analysis of the effectiveness of the organization of transportation, based on the calculation of qualitative and quantitative performance indicators, the main tool of the proposed methodological approach is the desirability function, supplemented by the calculation of the integrated coefficient.

2. The proposed integrated indicator of the level of investment potential of an automobile enterprise gives an opportunity to comprehensively approach to the estimation of activity and management of an enterprise and to specify separate processes which need to be improved. Implementation of the developed measures will enable to increase the overall efficiency of management of the motor transport enterprise and, accordingly, increase its investment attractiveness for potential investors.

\section{References}

1. Bazyliuk A. V. Hopdiienko V. V. (2013). Mechanism for the realization of the investment potential of auto-pumping enterprises in Ukraine. Aktual'ni problemy ekonomiky. 10. 84-92.

2. Hudkova V. P. (2013). Methodology of providing efficient activity of enterprises of passenger transportation sphere. Kyiv. DETUT.

3. Scherban' O. D. (2010). Approach to the rating assessment of the priority of investing in motor transport enterprises. Problemy i perspektyvy ekonomichnoho rozvytku pidpryiemstva. 20. 59-61.

4. Wang T. (2016). New Modern Logistics [M]. Beijing: Capital University of Economics Press.

5. Coyle J. J., Bardi E. J., Langley C. J. (2010). The Management of Business Logistics, St. Paul (Minn.): West Publishing Co.

6. Larina R. R., Cherep O. H., Hrishyn I. Yu. (2011). Models and methods of logistic management by subjects of economy and economy of the region. Simferopol': VD «ARIAL».

7. Tseng Y., Yue W., Aptaylor M. (2015). The role of transportation in logistics chain. Proceedings of the Eastern Asia Society for Transportation Studies. 5. 16571672.

8. Babyna O. Ye. (2013). System-humanization concept of formation and realization of the potential of the enterprise in the conditions of knowledge economy. Kyiv. SIK HRUP.

9. Zagurskiy O., Rogach S., Titova L., Rogovskii I., Pokusa T. (2019). "Green» supply chain as a path to sustainable development. Mechanisms of stimulation of socio-economic development of regions in conditions of transformation. Monograph. Opole: The Academy of Management and Administration in Opole. 199-213.

10. Zagurskiy O., Ohiienko M., Pokusa T., Zagurska S., Pokusa F., Titova L., Rogovskii I. (2020). Study of efficiency of transport processes of supply chains management under uncertainty. Monograph. Opole: The Academy of Management and Administration in Opole. 162.

\section{Список літератури}

1. Bazyliuk A. V. Hopdiienko V. V. Mechanism for the realization of the investment potential of autopumping enterprises in Ukraine. Aktual'ni problemy ekonomiky. 2013. Vol. 10. P. 84-92.

2. Hudkova $V$. P. Methodology of providing efficient activity of enterprises of passenger transportation sphere. Kyiv. DETUT. 2013.

3. Scherban' $O$. D. Approach to the rating assessment of the priority of investing in motor transport enterprises. Problemy i perspektyvy ekonomichnoho rozvytku pidpryiemstva. 2010. Vol. 20. P. 59-61.

4. Wang T. New Modern Logistics [M]. Beijing: Capital University of Economics Press. 2016.

5. Coyle J. J., Bardi E. J., Langley C. J. The Management of Business Logistics, St. Paul (Minn.): West Publishing Co. 2010.

6. Larina R. R., Cherep O. H., Hrishyn I. Yu. Models and methods of logistic management by subjects of economy and economy of the region. Simferopol': VD «ARIAL». 2011.

7. Tseng Y., Yue W., Aptaylor M. The role of transportation in logistics chain. Proceedings of the Eastern Asia Society for Transportation Studies. 2015. Vol. 5. P. 1657-1672.

8. Babyna O.Ye. System-humanization concept of formation and realization of the potential of the enterprise in the conditions of knowledge economy. Kyiv. SIK HRUP. 2013.

9. Zagurskiy O., Rogach S., Titova L., Rogovskii I., Pokusa T. «Green» supply chain as a path to sustainable development. Mechanisms of stimulation of socioeconomic development of regions in conditions of transformation. Monograph. Opole: The Academy of Management and Administration in Opole. 2019. P. 199213.

10. Zagurskiy O., Ohiienko M., Pokusa T., Zagurska S., Pokusa F., Titova L., Rogovskii I. Study of efficiency of transport processes of supply chains management under uncertainty. Monograph. Opole: The Academy of Management and Administration in Opole. 2020. 162 p. 


\section{ІННОВАЦІЙНИЙ ПІДХІД ДО ОЦІНКИ ІНВЕСТИЦЙНОГО ПОТЕНЦАЛУ АВТОТРАНСПОРТНОГО ПІДПРИЕМСТВА О. М. Загурський}

Анотація. За сучасних економічних умов та глобалізаційних процесів підприємство дедалі більше стає складною, динамічною системою, здатною за рахунок підвищення ефективності виробничих процесів до удосконалення i самоорганізації. Об'єктивно зростає значення ефективності у виробничій, інвестиційній i фінансовій діяльності, рівновазі і гнучкості стратегічних i тактичних управлінських рішень господарюючих суб'єктів.

Для підприємств автотранспортної сфери, як учасників виробничих процесів 3 переміщення в просторі та в часі різноманітних вантажів, відповідальність за прийняті управлінські рішення та наслідки ї господарської діяльності має особливе значення. Адже їх ефективність сприяє не лише зростанню власної конкурентоспроможності, а суттєво впливає на конкурентоспроможність підприємств замовників та загальний рівень конкурентоспроможності економіки країни.

В статті розроблено методологічний підхід заснований на розрахунку якісних i кількісних показників ефективності діяльності автотранспортного підприємства, що узагальнює систему показників оцінки його інвестиційного потенціалу.

Основним інструментом пропонованого підходу є функція бажаності, доповнена обчисленням інтегрованого коефіцієнта та застосуванням об'єктивно структурного підходу для зниження суб'єктивності неформалізованих показників.

Розроблений підхід узагальнюе систему показників оцінки інвестиційного потенціалу автотранспортного підприємства i служить інструментом визначення іï рівня. Запропонований інтегрований показник рівня інвестиційного потенціалу автотранспортного підприємства дає можливість комплексно підійти до оцінки діяльності і управління підприємством та виокремити окремі процеси, які потрібно вдосконалювати.

Реалізація розроблених заходів дасть можливість підвищити загальну ефективність управління автотранспортним підприємством i відповідно збільшити його інвестиційну привабливість для потенційних інвесторів.

Ключові слова: автотранспортне підприємство, ефективність, інвестиційний потенціал, інтегрований показник, комплексний аналіз.

\section{ИННОВАЦИОННЫЙ ПОДХОД К ОЦЕНКЕ ИНВЕСТИЦИОННОГО ПОТЕНЦИАЛА АВТОТРАНСПОРТНОГО ПРЕДПРИЯТИЯ О. Н. Загурский}

Аннотация. В современных экономических условиях и глобализационных процессах предприятие все больше становится сложной, динамичной системой, способной за счет повышения эффективности производственных процессов к совершенствованию и самоорганизации. Объективно возрастает значение эффективности в производственной, инвестиционной и финансовой деятельности, равновесии и гибкости стратегических и тактических управленческих решений хозяйствующих субъектов.

Для предприятий автотранспортной сферы, как участников производственных процессов по перемещению в пространстве и во времени различных грузов, ответственность за принятые управленческие решения и последствия их хозяйственной деятельности имеет особое значение. Ведь их эффективность способствует не только росту собственной конкурентоспособности, а существенно влияет на конкурентоспособность предприятий заказчиков и общий уровень конкурентоспособности экономики страны.

В статье разработан методологический подход который основан на расчете качественных и количественных показателей эффективности деятельности автотранспортного предприятия, обобщает систему показателей оценки его инвестиционного потенциала.

Основным инструментом предлагаемого подхода является функция желательности, дополненная вычислением интегрированного коэффициента и применением объективно структурного подхода для снижения субъективности неформализованных показателей.

Разработанный подход обобщает систему показателей оценки инвестиционного потенциала автотранспортного предприятия и служит инструментом определения ее уровня. Предложенный интегрированный показатель уровня инвестиционного потенциала автотранспортного предприятия дает возможность комплексно подойти к оценке деятельности и управления предприятием и выделить отдельные процессы, которые нужно совершенствовать.

Реализация разработанных мероприятий позволит повысить общую эффективность управления автотранспортным предприятием и соответственно увеличить его инвестиционную привлекательность для потенциальных инвесторов.

Ключевые слова: автотранспортное предприятие, эффективность, инвестиционный потенциал, интегрированный показатель, комплексный анализ.

\section{О. М. Загурський ORCID 0000-0002-5407-8466.}

